\title{
The Copper (I) Chelator Neocuproine Inhibits Mouse Bladder Function, but not the Copper (II) Chelator Cuprizone
}

\author{
Bakır (I) Şelatörü Neocuproine Fare Mesane Fonksiyonunu İnhibe Eder, Ancak Bakır (II) Şelatörü Cuprizone İnhibe
}

Etmez

\section{${ }^{1}$ Nadire Eser, ${ }^{2} \mathrm{H}$.Sinem Buyuknacar, ${ }^{3}$ Eda Kumcu, ${ }^{3}$ Cemil Gocmen}

(11)
'Kahramanmaras Sutcu Imam University, Faculty of Medicine, Department of Pharmacology, Kahramanmaras, Turkey

${ }^{2}$ Cukurova University, Faculty of Pharmacy, Department of Pharmacology, Adana, Turkey

${ }^{3}$ Cukurova University, Faculty of Medici ne, Department of Pharmacology, Adana, Turkey

\section{Correspondence:}

Nadire ESER-- Kahramanmaras Sutcu Imam University, Faculty of Medicine, Department of Pharmacology, Kahramanmaras, Turkey

e-mail: esernadire01@hotmail.com

\section{Abstract}

The aim of this study was to investigate the effect of neocuproine (NC), a selective $\mathrm{Cu}(\mathrm{I})$ chelator, on the spontaneous contractions (SC) and basal tension (BT) in isolated mouse bladder tissues. The spontaneous contractions and basal tension in the isolated bladder strips were recorded to evaluate the amplitude and frequency parameters. NC $(100 \mu \mathrm{M})$ caused a significant inhibition on spontaneous contractions (SC) in the isolated mouse bladder. We also evaluated the effects of cuprizone, a selective $\mathrm{Cu}$ (II)-chelator, and various selective or non-selective purinoceptor antagonists on the SC and also on the basal tension (BT). Of them, a non-selective purinergic antagonist suramin, a P2X receptor antagonist PPADS, a P2X3 antagonist NF 110, a P2 receptor activator ATP or a P2Y1 antagonist MRS 2179 significantly reversed $\mathrm{NC}$-induced inhibition on the SC whereas cuprizone was found ineffective. The results showed that both $\mathrm{P} 2 \mathrm{X}$ and $\mathrm{P} 2 \mathrm{Y}$ receptors are playing role in the inhibitory effect of NC on the mouse bladder function. Ca2+ addition to the organ bath medium also dose-dependently reversed the NC-induced inhibition suggesting the role of myogenic mechanism. These findings suggest that intracellular calcium reduction, purinergic pathway and $\mathrm{Cu}(\mathrm{I})$ but not $\mathrm{Cu}(\mathrm{II})$ may have an important role in the inhibitory activity of $\mathrm{NC}$ on mouse bladder function.

Keywords: Bladder activity, neocuproine, copper(I) chelator, $\mathrm{Cu}(\mathrm{II})$-chelator, mouse, purinoceptors

\section{Özet}

$\mathrm{Bu}$ çalışmanın amacı, seçici bir $\mathrm{Cu}(\mathrm{I})$ şelatörü olan neocuproine'in (NC) izole fare mesane dokularındaki spontan kasılmalar (SK) ve bazal gerginlik (BT) üzerindeki etkisini araştırmaktır. İzole mesane striplerinde spontan kasılmalar ve bazal tonus, amplitude ve frekans parametreleri değerlendirilmiștir. Ayrıca selektif bir $\mathrm{Cu}(\mathrm{II})$-șelatör olan cuprizone’un ve çeșitli selektif ve nonselektif purinoseptör antagonistlerinin spontan kasılmalar ve bazal tonus (BT) üzerindeki etkileri de değerlendirildi. NC (100 $\mu \mathrm{M})$, izole edilmiş fare mesanesinde spontan kasılmalar üzerinde önemli bir inhibisyona neden olmuştur. Bunlardan nonselektif bir purinerjik antagonist olan suramin, bir P2X reseptör antagonisti PPADS, bir P2X3 antagonisti NF 110, bir P2 reseptör aktivatörü ATP veya bir P2Y1 antagonisti MRS 2179, spontan kasılmalar üzerinde NC'in neden olduğu inhibisyonu önemli ölçüde tersine çevirirken cuprizone etkisiz bulundu. Sonuçlar, NC'nin fare mesane islevi üzerindeki inhibitör etkisinde hem P2X hem de P2Y reseptörlerinin rol oynadığını göstermektedir. Organ banyosu ortamına Ca2+ ilavesi de doza bağlı olarak NC ile indüklenen inhibisyonu tersine çevirerek miyojenik mekanizmanın rolü olabileceğini düşündürdü. Bu bulgular, hücre içi kalsiyum azalmasının, purinerjik yolun ve $\mathrm{Cu}(\mathrm{I})$ 'in, fare mesane fonksiyonu üzerindeki NC'nin inhibe edici aktivitesinde önemli bir role sahip olabildiğini, $\mathrm{Cu}(\mathrm{II})$ ' nin etkisiz olduğunu göstermektedir

Anahtar Kelimeler: Mesane aktivitesi, neocuproine, bakır(I) şelatörü, bakır(II) şelatörü, fare, purinoseptörler 


\section{Introduction}

ATP (adenosine5'-triphosphate) has been identified as nonadrenergic-noncholinergic (NANC) transmitter in the lower urinary tract(1-3) and it regulates many cell functions by acting on special types of receptors, called P2 purinoceptors $(4,5)$. According to the current classification, $\mathrm{P} 2$ receptors are divided into two families: P2X, elicits contractile responses through ligand-gated-ion-channels, and P2Y, elicits relaxant responses through Gprotein-coupled receptors $(6,7)$. Burnstock showed the main distributions of $\mathrm{P} 2 \mathrm{X}$ and $\mathrm{P} 2 \mathrm{Y}$ receptors $(8)$. Functional $\mathrm{P} 2 \mathrm{X}$ and $\mathrm{P} 2 \mathrm{Y}$ purinergic receptors have been identified in different kinds of species such as mouse, rat, guinea pig and human urothelial cells(9-12).

The imbalance homeostasis of copper ions, has long been known in humans, causes serious health problems, and it is known that the copper removes from the body through the urine(13). Herewith, the investigation of copper mechanism on bladder activity is potentially important. Although there has been an increasing number of studies on the therapeutic value of copper and copper chelators in clinical use in recent years, there are no sufficient preclinical/clinical studies demonstrating the effects of these agents on bladder functions $(13,14)$. To demonstrate the contribution of copper-dependent mechanisms in regulation of purinergic and nitrergic mechanisms in the mouse bladder, we investigated the effects of a selective $\mathrm{Cu}(\mathrm{I})$ chelator, NC (2,9-dimethyl-1,10phenanthroline)(15,16), and a selective $\mathrm{Cu}(\mathrm{II})$-chelator, cuprizone(15), on neurally evoked contractions, SC and $\mathrm{BT}$ of mouse bladder strips.

Our previous studies showed that the chelation of endogenous copper(I) caused an enhancement on the spontaneous activity in some of rat tissues such as bladder and vas deferens tissues of rats and pregnant rat myometrium(16-19) and the involvement of purinergic receptors and/or $\mathrm{Ca}^{2+}$ levels in those responses. In the present study, our aim was to evaluate whether the contribution of purinergic pathways and/or intracellular calcium levels in the effects of neocuproine in the mouse bladder tissues are similar to rat tissues or not. Therefore, in this study, we investigated the inhibitor effect of a selective $\mathrm{Cu}(\mathrm{I})$ chelator, neocuproine, a selective $\mathrm{Cu}(\mathrm{II})$ chelator, cuprizone, intracellular calcium addition and purinergic antagonists on the spontaneous contractions (SC) of the isolated mouse bladder strips.

\section{Material and Methods}

\section{Animals}

Both sex of 40 adult Swiss albino mice (25$35 \mathrm{~g}$ weight; 2-4 months-old) were used in this study. The experimental procedures were approved by the animal care committee of the University of Cukurova (Protocol no: 11/173 ) and the studies were carried out in accordance with the Canadian Council on Animal Care (CCAC) guidelines or the Guide for the Care and Use of Laboratory Animals (8th edition, National Academies Press). All animals were kept under standard laboratory conditions (12 h light/12 h dark).

\section{In vitro isolated organ bath studies}

Sevoflurane anesthetized mice $(n=40)$ were sacrificed by decapitation and then detrusor muscle strips $(5 \times 1 \mathrm{~mm}$ longitudinal sections $)$ were prepared from the midportion of bladder-body as in previous studies $(19,20)$. Two strips of each mouse were subsequently mounted in 5-ml jacketed organ baths containing Krebs solution (mM; $\mathrm{NaCl} 119$, $\mathrm{KCl} 4.6, \mathrm{CaCl}_{2} 1.25, \mathrm{MgSO}_{4}, 1.2, \mathrm{KH}_{2} \mathrm{PO}_{4}$ 1.2, $\mathrm{NaHCO}_{3}$ 24.8, and dextrose 10) maintained at $37^{\circ} \mathrm{C}$ and bubbled with a mixture of $95 \% \mathrm{O}_{2}$ and $5 \% \mathrm{CO}_{2}$ at $\mathrm{pH} 7.4$ under $500 \mathrm{mg}$ tension. Tissues then were allowed to equilibrate for $1 \mathrm{~h}$ and washed with fresh Krebs solution at $15 \mathrm{~min}$ intervals during the incubation. After that, the SC were recorded with isometric transducer (MAY COM, FDT 10-A) for $4 \mathrm{~h}$ to evaluate the stability of the amplitude and frequency parameters of mouse bladder strips. In each group, KCL was applied to the tissue at the end of the experiment to evaluate the tension as a percentage of $\mathrm{KCl}$-induced contraction. Data were recorded and stored using Biopac data acquisition software (Biopac MP35 Systems, Inc.). 
In the first group, two series of experiments were performed with an interval of 30 $\min (19)$ in the experiments evaluated the SC of the bladder strips. The effects of various agents including, $\mathrm{CaCl}_{2}(3$ and $6 \mathrm{mM})$, prepared NC-copper(I)-complex (Glutatione $+\mathrm{NC}+\mathrm{CuCl}_{2}$ ), a nitric oxide synthase inhibitor L-Nitroarginine (LNOARG; $0.5 \mathrm{mM}$ ), a selective $\mathrm{Cu}(\mathrm{II})$-chelator cuprizone $(5 \mu \mathrm{M})$, a non-selective purinergic antagonist suramin $(100 \mu \mathrm{M})$, a P2X receptor antagonist PPADS $(200 \mu \mathrm{M})$, a P2X1 purinergic antagonist NF449 $(20 \mu \mathrm{M})$, a P2X2 purinergic antagonist A-317491 $(20 \mu \mathrm{M})$, a P2X3 purinergic receptor antagonist NF110 $(20 \mu \mathrm{M})$, a P2Y1 purinergic antagonist MRS2179 $(20 \mu \mathrm{M})$ or a P2Y2 purinergic antagonist PSB1114 $(20 \mu \mathrm{M})$ was examined in the presence or absence of neocuproine. The neocuproine-copper(I)-complex was prepared by reacting glutathione, neocuproine, and $\mathrm{CuCl}_{2}$ in molar ratios of 1:2:1, respectively(18). In addition, the following agents, carbachol $(0.01 \mu \mathrm{M})$, subtance-P (5 $\mu \mathrm{M})$, 4-aminopyridine $(100 \mu \mathrm{M})$, or $10 \mathrm{mM}$ $\mathrm{KCl}$ were also investigated on the spontaneous contractions. Effect of NC (100 $\mu \mathrm{M})$ was also evaluated on these facilitated contractions.

In the other group, we studied the effect of exogenous ATP on BT and SC of the bladder strips. ATP $(10,50$, or $100 \mu \mathrm{M})$ was applied four times to the same tissue consecutively at intervals 10-15 min. Exposure time of ATP was $60 \mathrm{~s}$ for each application(19).

\section{Drugs}

PPADS, NF449, A-317491, NF110, MRS2179 and PSB1114 were obtained from Tocris. Neocuproine, L-Nitroarginine, carbachol, 4-Aminopyridine, Substance-P, atropine, guanethidine, ATP, $\alpha-\beta$-methylene ATP and cuprizone were obtained from Sigma-Aldrich, St. Louis, MO. All drugs were diluted in distilled water except cuprizone. Cuprizone was dissolved in $50 \%$ ethylalcohol.

\section{Statistical Analysis}

The spontaneous contractions (SC) activity was quantified by calculation the maximal amplitude (g) and the frequency (contractions per min). Amplitude and developed tension of each drug application were expressed as a percentage of $100 \mathrm{mM} \quad \mathrm{KCl}$-induced contraction applied at the end of each experiment. All data were expressed as mean \pm S.E. and evaluated with the Bonferroni corrected $t$ test that was used in analysis of variance (ANOVA). $P<0.05$ were considered significant. Statistical analysis was performed with GraphPad Prism software (San Diego, CA, USA).

\section{Results}

The profile of spontaneous contractions in the isolated mouse bladder strips

In the control experiments, $2 \mu \mathrm{M}$ atropine and $2 \mu \mathrm{M}$ guanethidine were always present in the organ bath to block adrenergic and cholinergic transmission. The SC of isolated bladders of mice were recorded for $4 \mathrm{~h}$ period to evaluate the stability of the tissues. During this time, the amplitude and frequency of SC did not change significantly. The average amplitudes and frequencies recorded at the end of the $1 \mathrm{~h}$ incubation was $0.11 \pm 0.01 \mathrm{mg}$ and $7 \pm 1 / \mathrm{min}$ respectively.

The effect of NC on the spontaneous contractions and the effect of suramin on $\mathrm{NC}$ induced inhibition of spontaneous contractions in the isolated mouse bladder strips

NC $(100 \mu \mathrm{M})$ caused a significant and reversible inhibition on the amplitude of basal $\mathrm{SC}$ in the isolated mouse bladder strips (Fig. 1A). No significant difference was observed on the frequency of bladder strips in the peresence of NC (Control: $9.7 \pm 0.6 / \mathrm{min}, \mathrm{NC}$ : $8.0 \pm 0.5 / \mathrm{min})$. NC also caused an inhibition on basal tension (BT; $45.5 \% \pm 0.08$ ). Responses to NC were reversible and reproducible (Fig. 1A). After NC application, the tissues were washed with fresh Krebs solution and then BT and SC returned to baseline values. 
A nonspesific purinergic receptor antagonist suramin alone $(100 \mu \mathrm{M})$ had no effect on the amplitude of basal SC and BT (Fig. 1B), but NC-induced decrease of SC and BT were significantly reversed in the presence of suramin (Fig. 1B).

The effect of $\mathrm{CaCl}_{2}$ on NC-induced inhibition in the isolated mouse bladder strips
NC $(100 \mu \mathrm{M})$ caused a statisticaly significant inhibition on the $\mathrm{SC}$ of the mouse bladder tissues. Addition of $\mathrm{CaCl}_{2}$ to the organ bath medium with an interval of $5 \mathrm{~min}$ at different concentrations ( 3 or $6 \mathrm{mM}$ ) significantly and dose-dependently reversed the $\mathrm{NC}$-induced inhibition. (Fig. 1C). Likewise, the addition of $\mathrm{CaCl}_{2}$ completely reversed the $\mathrm{NC}$-induced inhibition on the BT (Data not shown).
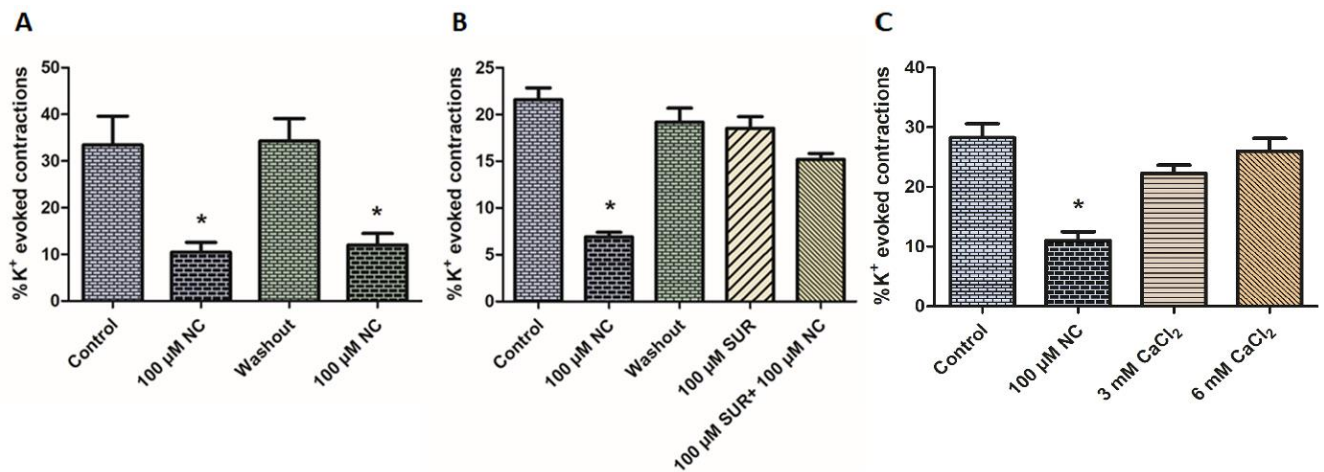

Figure 1. The effect of $100 \mu \mathrm{M}$ Neocuproine (NC) on the amplitude of the spontaneous contractions in the isolated mouse bladder strips (A). The effect of Suramin (SUR; $100 \mu \mathrm{M})(\mathbf{B})$ on $100 \mu \mathrm{M}$ NC-induced inhibition on the amplitude of spontaneous contractions of the isolated mouse bladder tissue. The effects of 3 or $6 \mathrm{mM}$ Calcium chloride $\left(\mathrm{CaCl}_{2}\right)$ addition $(\mathbf{C})$ on $100 \mu \mathrm{M} \mathrm{NC}$-induced inhibition of spontaneous contractions in the isolated mouse bladder tissues. $\left(^{*}\right)$ indicates statistical significance compared to control $(\mathrm{p}<0.05)$.

The effect of $\mathrm{NC}$-Cu(I)-complex, cuprizone or L-NOARG on neocuproine-induced inhibition of spontaneous contractions in the isolated mouse bladder strips

NC-induced inhibition on the SC was not observed in the presence of $\mathrm{NC}-\mathrm{Cu}(\mathrm{I})$ complex in the isolated mouse bladder strips (Fig. 2A). $\mathrm{NC}-\mathrm{Cu}(\mathrm{I})$-complex had no significant effect on the frequency and amplitude parameters of SC and BT (Fig. 2A).
Administration of $50 \mu \mathrm{M}$ cuprizone alone did not cause any effect on the amplitude, frequency of basal SC in the isolated mouse bladder strips and Control: 3.37 \pm 0.99 , Cuprizone: $2.83 \pm 0.45$. Cuprizone also had no effect on the inhibition of SC induced by $\mathrm{NC}$ (data not shown).

$100 \mu \mathrm{M}$ L-NOARG had no effect on basal SC and BT. Likewise, L-NOARG did not affect the NC-induced inhibition on SC and BT in the isolated mouse bladder strips (Fig. 2B). 

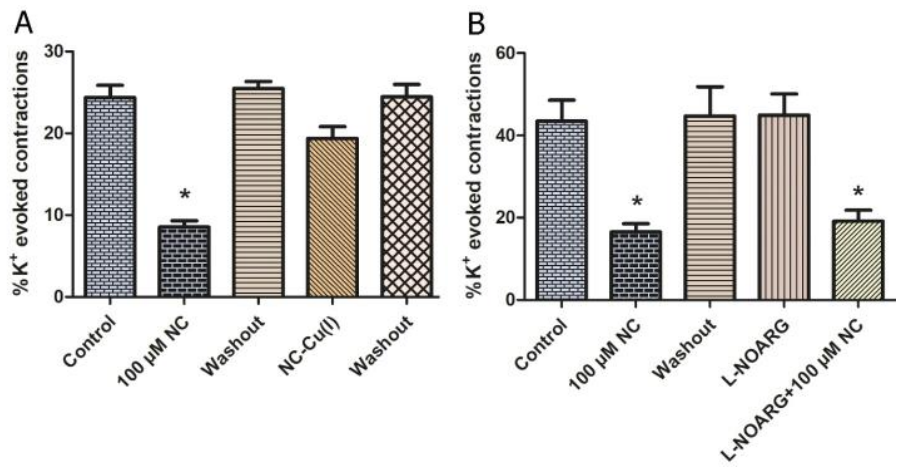

Figure 2. The effect of neocuproine-copper (I) complex [NC-Cu (1)] (A) and $100 \mu \mathrm{M}$ L-NOARG (B) on $100 \mu \mathrm{M}$ neocuproine (NC)-induced inhibition on spontaneous contractions of isolated mouse bladder tissue. $(*)$ indicates statistical significance compared to control $(\mathrm{p}<0.05)$.

The effect of NC on spontaneous contractions stimulated with carbachol, 4-aminopridine, substance $P$ or $10 \mathrm{mM} \mathrm{KCl}$ on the isolated mouse bladder strips

The SC were facilitated by a muscarinic receptor agonist carbachol $(0.05 \mu \mathrm{M})$, a voltage-gated $\mathrm{K}^{+}$channel blocker 4aminopyridine $(100 \mu \mathrm{M})$, a tachykinin peptide substance-P $(5 \mu \mathrm{M})$ or $10 \mathrm{mM} \mathrm{KCl}$ on isolated mouse isolated bladder. $100 \mu \mathrm{M}$ of $\mathrm{NC}$ resulted in a significant inhibition on those contractions $(\%$ percentages of inhibition: $31.1 \pm 3.08$ for carbachol, $40.6 \pm 6.2$ for subtance-P, $33.8 \pm 6.2$ for 4 -aminopyridine and $44.1 \pm 4.5$ for $\mathrm{KCl})$ in the isolated bladder strips (data not shown).
The effect of PPADS, NF449, A-317491 and NF110 on NC-induced inhibition on isolated mouse bladder strips

Administration of $200 \mu \mathrm{M}$ PPADS, $20 \mu \mathrm{M}$ NF449, $20 \mu \mathrm{M}$ A-317491 or $20 \mu \mathrm{M}$ NF110 alone did not elicit statistically significant effect on the amplitude parameter of basal SC and BT (Fig. 3A, B, C and D). However, PPADS or NF110 significantly reversed NCinduced-inhibition on amplitude of SC in the isolated bladder strips (Fig. 3A, D) whereas administration of NF449 and A-317491 to the stirps reversed partially but not significantly NC-induced-inhibition (Fig. 3B, C). Drugs alone or in the presence of $\mathrm{NC}$ had no effect on the frequency of SC.

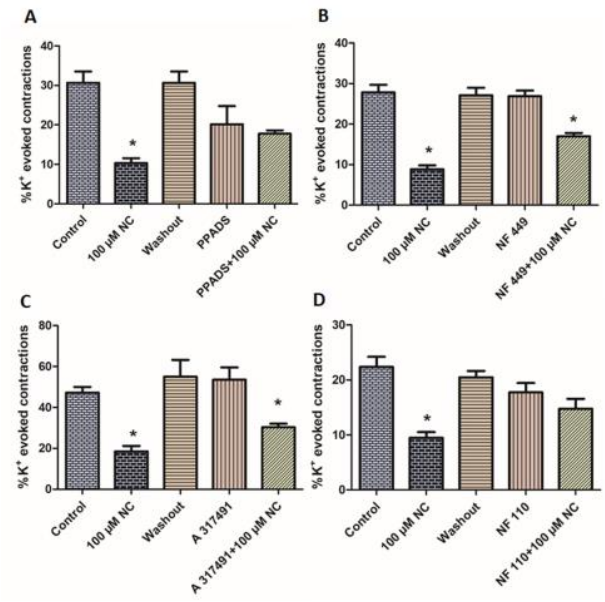

Figure 3. The effect of $200 \mu \mathrm{M}$ PPADS (A), $20 \mu \mathrm{M}$ NF449 (B), $20 \mu \mathrm{M}$ A-317491(C) and $20 \mu \mathrm{M}$ NF110 (D) on 100 $\mu \mathrm{M}$ neocuproine (NC)-induced inhibition on the amplitude of spontaneous contractions of isolated mouse bladder tissue. $(*)$ indicates statistical significance compared to control $(\mathrm{p}<0.05)$. 
The effect of MRS2179, PSB1114, ATP and $\alpha-\beta$-methylene ATP on NC-induced-inhibition on isolated mouse bladder strips

$20 \mu \mathrm{M}$ MRS2179, $20 \mu \mathrm{M}$ PSB1114, $20 \mu \mathrm{M}$ ATP or $20 \mu \mathrm{M} \alpha-\beta$-methylene ATP alone had no effect on the amplitude of SC (Fig. 4A, B, C and D). But MRS 2179 or ATP could significantly reversed the NC-induced-inhibition on the SC (Fig. 4A and C) whereas administration of PSB1114 or alpha-beta methylene ATP to the bladder strips reversed partially but not significantly the NC-induced-inhibition (Fig. 4B and D). Drugs alone or in the presence of NC had no effect on the frequency of SC.

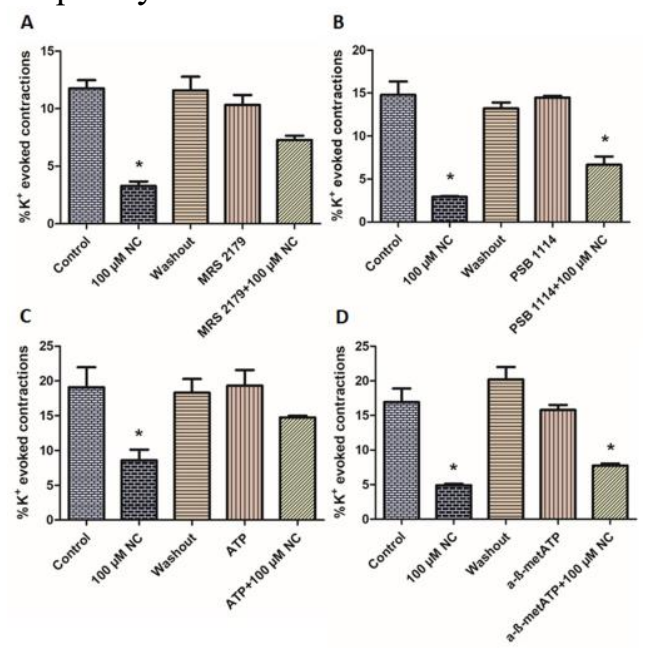

Figure 4. The effect of $20 \mu \mathrm{M}$ MRS2179 (A), $20 \mu \mathrm{M}$ PSB1114 (B), $20 \mu \mathrm{M}$ ATP (C) and $20 \mu \mathrm{M}$ alpha-beta methylene ATP ( $\alpha$ - $\beta$-metATP) (D) on $100 \mu \mathrm{M}$ neocuproine (NC)-induced inhibition on the amplitude of spontaneous contractions of isolated mouse bladder tissue. $\left({ }^{*}\right)$ indicates statistical significance compared to control $(\mathrm{p}<0.05)$.

\section{Discussion}

In this study, we evaluated the stability of the $\mathrm{SC}$ in the isolated mouse bladder strips and also investigated the effect of a copper(I)chelator, NC on those contractions in this tissue. The main findings can be summarized as follows: (i) $\mathrm{NC}$ caused a significant inhibition on the amplitude of SC whereas cuprizone, a copper (II) chelator did not; (ii) $\mathrm{NC}-\mathrm{Cu}(\mathrm{I})$-complex significantly reversed the reduction observed with NC; (iii) Purinergicreceptor antagonists had shown partial significant effect on the inhibitor effect of $\mathrm{NC}$; (iv) $\mathrm{CaCl}_{2}$ addition to the organ bath medium dose-dependently caused (v) LNOARG was found inffective on the NCinduced-inhibition.

Ding et al., clarified the clinical use of copper chelators in some aspects; understanding of the molecular basis, treatment for diseases, related with copper alterations, and the diagnostic application to impaired copper metabolism(13). In agreement with the aspect of understanding the mechanism of copper

chelators, in the present study, the effect of $\mathrm{NC}$ on spontaneous contractions was evaluated. $\mathrm{NC}$ elicited a reproducible and reversible decrease on the $\mathrm{BT}$ and the amplitude parameter of SC but not frequency in the isolated mouse bladder strips in the present study. $\mathrm{NC}-\mathrm{Cu}(\mathrm{I})$-complex significantly reversed the inhibition of $\mathrm{NC}$ observed on the SC. However $\mathrm{Cu}(\mathrm{II})$-chelator, cuprizone had no effect on the SC. Decrease on the SC-induced by $\mathrm{NC}$ but not cuprizone indicated that a copper(I)-sensitive mechanism may play a role in the inhibitor effect of $\mathrm{NC}$ in the mouse bladder. The activity/inactivity of copper chelators are in agreement with our previous studies conducted on rat bladder and vas deferens $(17,19)$. However in the rat urinary bladder, L-NOARG, a nitric oxide synthase inhibitor, had no effect on the facilitator effect of $\mathrm{NC}$ on nerve-evoked contractions. This is similar with the present study which was shown the ineffectiveness of L-NOARG on 
NC-induced inhibition(19). It can be suggested that the L-arginine-NO pathway has not any role in the inhibitor activity of $\mathrm{NC}$ on the SC on nitrergic mechanism of mouse bladder. Because it was observed that purinoceptors and transmission contribute to SC of bladder tissue $(1,20)$, we investigated purinergic receptor antagonists both on the $\mathrm{SC}$ and on the inhibitor effect of neocuproine to examine the interaction between copper and purinoceptors.

Suramin, a nonspecific $\mathrm{P} 2 \mathrm{X}$ purinergic receptor antagonist, significantly reversed the $\mathrm{NC}$-induced inhibitory effect on the isolated mouse bladder strips suggesting that NCinduced inhibition may associate with the purinergic mechanism and it may be an interaction between $\mathrm{P} 2 \mathrm{X}$ receptors and copper(I)(5,6). As reported in the study carried out in the isolated human bladder, it was observed that ATP-induced contractions were abolished by $\mathrm{P} 2 \mathrm{X}$ receptor desensitization with $\alpha, \beta$-methylene $\operatorname{ATP}(5)$. It was known that ATP released from urothelial cells acts on $\mathrm{P} 2 \mathrm{X} 3$ and $\mathrm{P} 2 \mathrm{X} 2 / 3$ receptors and initiates voiding reflex(1). In our study we used the antagonists of purinergic receptor subtypes and found that NC-induced inhibitory effect was partially prevented by P2X receptor blocker PPADS, P2X1 purinergic receptor antagonist NF449, P2X2 purinergic receptor antagonist A-317491 and P2X3 purinergic receptor antagonist NF110. Preventive effects of P2X1-X3 antagonists indicate that $\mathrm{P} 2 \mathrm{X}$ receptor subtypes are also involved in the effect of NC. Because P2X receptors are ATP-gated cation channels $(7,21)$, modulation of ATP may play role in the inhibitor effect of $\mathrm{NC}$ on the spontaneous contractions. Previous studies showed that $\mathrm{P} 2 \mathrm{X}$, especially $\mathrm{P} 2 \mathrm{X} 3$ receptor plays an important role in mechanosensory transduction in the mouse urinary bladder(5,7,22). It is well known that primary afferent neurons, especially $\mathrm{C}$ fibers, are activated by $\mathrm{P} 2 \mathrm{X} 3$ receptors(23). So AF-219, more recently developed $\mathrm{P} 2 \mathrm{X} 3$ and $\mathrm{P} 2 \mathrm{X} 2 / 3$ antagonist, the aryloxy-pyrimidinediamine, which is orally bioavailable and metabolically stable, is being explored as a therapeutic agent for urinary tract dysfunction.
However one of the main cause initiating this study was the hypothesis that $\mathrm{P} 2 \mathrm{Y}$ receptor subtypes may play a major role in the inhibitory mechanism of neocuproine. Besides $\mathrm{P} 2 \mathrm{X}$ receptors, it is also known that $\mathrm{P} 2 \mathrm{Y}$ receptors are also contibuted to urinary system function. Chopra et al., showed that $\mathrm{P}_{2} \mathrm{Y}_{2}$ receptors express from urothelial cells and UTP is the most potent agonist of those receptors(10). It is known that $\mathrm{P} 2 \mathrm{Y}$ receptors have inhibitory effect on bladder contraction $(24,25)$. Therefore we evaluated the effects of some P2Y receptor antagonists on the supressor effect of NC. MRS2179, a P2Y1 purinoceptor antagonist, significantly reversed the inhibitory effect of NC on the SC in mouse bladder. These results indicate that both $\mathrm{P} 2 \mathrm{X}$ and $\mathrm{P} 2 \mathrm{Y}$ receptor subtypes are involved in the inhibitory effect of $\mathrm{NC}$ in mouse bladder. Antagonism of P2X or P2Y receptor subtypes significantly reversed the $\mathrm{SC}$ inhibited by NC. That NC-Cu(I)-complex has a similar effect on the supressor effect of $\mathrm{NC}$, it can be suggested that $\mathrm{Cu}(\mathrm{I})$ may have an important role in the stability and regulation of $\mathrm{SC}$ in the mouse bladder. $\mathrm{Cu}(\mathrm{I})$ chelation may also promote purinoceptor activation because of partial reversal effect elicited by purinergic receptor antagonists of the SC. The presence of purinergic receptors mediated relaxation such as $\mathrm{P} 2 \mathrm{Y}$ has been demonstrated on the bladder(5). However, that selective $\mathrm{P} 2 \mathrm{X}$ receptor antagonists also significantly reversed the inhibition is making difficult to understand the mechanism of inhibitory effect of NC.

In the rat isolated aorta, ATP reveals contraction by exciting P2X-purinoceptor activation possibly through releasing $\mathrm{Ca}^{2+}$ from both extracellular and intracellular storage sites whereas $\alpha-\beta$-methylene ATP showed its effect only via extracellular calcium channels(26). In this study, ATP reversed significantly $\mathrm{NC}$-induced-inhibition on basal SC whereas $\alpha$ - $\beta$-methylene ATP did not. Also we found that NC-inducedinhibition on SC were dose-dependently and significantly reversed by administrating of 3 and $6 \mathrm{mM} \mathrm{CaCl}_{2}$ to the mouse bladder strips at $5 \mathrm{~min}$ intervals respectively. This finding shows that extracellular-calcium also plays a crucial role in NC-dependent-inhibitory 
mechanism. In a previous study on rat bladder, the suppression of the increase on NC-induced BT by calcium-channel blockers or the absence of this increament in calciumfree medium also supports our findings(19).

As well as purinergic mechanism, peptidergic transmission involving substance$\mathrm{P}$ or other neurokinins are thought to be involved in NANC transmission in the bladder(20). Similar results were also found in our study which we observed the inhibitor activity of $\mathrm{NC}$ on BT and SC activity induced by $10 \mathrm{mM} \mathrm{KCl}$ or cholinergic receptor agonist $\mathrm{CCh}$, or $\mathrm{K}^{+}$channel blocker 4-AP or an inflammatory mediator neurokinin receptor agonist substance $\mathrm{P}$, on the $\mathrm{SC}$ of isolated mouse bladder. These results demonstrated that the NC-induced ihibitor effect on the SC is not only related to the basal activity but also peptidergic transmission in the mouse bladder. In addition, the excitation effect of $\mathrm{NC}$ on neurogenic contractions in the isolated bladder strips supports that $\mathrm{NC}$ has an effect on myogenic activity.

\section{Conclusion}

In conclusion, inhibition of SC and BT with neocuproine, a copper(I) chelator, shows that a copper(I) may regulate the basal activity of the mouse bladder. That purinoceptor antagonists partly but significantly ameliorated the inhibitor effects of $\mathrm{NC}$ demonstrates the contribution of purinergic pathway on the NC-induced-inhibition of SC in the mouse bladder. The effect of $\mathrm{NC}$ on mouse bladder activity appears to be partly attributed to $\mathrm{P} 2 \mathrm{X}$ as well as $\mathrm{P} 2 \mathrm{Y}$ receptors. Reversal of $\mathrm{SC}$ with the addition of $\mathrm{CaCl}_{2}$ is the evidence that $\mathrm{NC}$ induces inhibition via reducing intracellular-calcium levels. However we need further studies to elucidate the NC-induced-inhibition mechanism on SC and the relationship between of purinoceptorsubtypes and copper(I). Purinoceptor expression studies in the mouse bladder will be useful for clarifying the NC-inducedinhibition mechanism. All these findings show that NC may be a beachhead to explore as a potential therapeutic agent in atonic bladder in future.

We would like to thank The Scientific and Technological Research Council of Turkey (TUBITAK) to support this study as a scholar of 1002 - Short Term R\&D Funding Program (112S016).

\section{REFERENCES}

1. Burnstock G. Purinergic signalling in the urinary tract in health and disease. Purinergic Signalling 2014;10:103-55.

2. Virgilio F Di, Sarti AC, Coutinho-Silva R. Purinergic signaling, DAMPs, and inflammation. American Journal of Physiology - Cell Physiology 2020;318:C832-5.

3. Ueda N, Kondo M, Takezawa K, et al. Bladder urothelium converts bacterial lipopolysaccharide information into neural signaling via an ATPmediated pathway to enhance the micturition reflex for rapid defense. Scientific Reports 2020;10:1-15.

4. Burnstock G. Introduction: ATP and Its Metabolites as Potent Extracellular Agents. Current Topics in Membranes 2003;54:1-27.

5. Kennedy C. The P2Y/P2X divide: How it began. Biochem Pharmacol. 2021;187:114408

6. Alexander SPH, Mathie A, Peters JA, et al. The Concise Guide to Pharmacology 2019/20: Ion channels. British Journal of Pharmacology 2019;176:S142-228.

7. Illes P, Müller CE, Jacobson KA, et al. Update of

P2X receptor properties and their pharmacology: Iuphar Review 30. British Journal of Pharmacology 2020;178:489-514.

8. Burnstock G. Therapeutic potential of purinergic signalling for diseases of the urinary tract. BJU International 2011;107:192-204.

9. Sui G, Fry CH, Montgomery B, Roberts M, Wu R, $\mathrm{Wu}$ C. Purinergic and muscarinic modulation of ATP release from the urothelium and its paracrine actions. American Journal of Physiology - Renal Physiology 2014;306:F286-98.

10. Chopra B, Gever J, Barrick SR, et al. Expression and function of rat urothelial P2Y receptors. American Journal of Physiology-Renal Physiology 2008;294:F821-9.

11. Shabir S, Cross W, Kirkwood LA, et al. Functional expression of purinergic $\mathrm{P} 2$ receptors and transient receptor potential channels by the human urothelium. American Journal of Physiology-Renal Physiology 2013;305:F396406.

12. Everaerts W, Vriens J, Owsianik G, et al. Functional characterization of transient receptor 
potential channels in mouse urothelial cells. American Journal of Physiology - Renal Physiology 2010;298:692-701.

13. Ding X, Xie H, Kang YJ. The significance of copper chelators in clinical and experimental application. Journal of Nutritional Biochemistry 2011;22:301-10.

14. Arnal N, De Alaniz MJT, Marra CA. Carnosine and neocuproine as neutralizing agents for copper overload-induced damages in cultured human cells. Chemico-Biological Interactions 2011;192:257-63.

15. De Man JG, Moreels TG, De Winter BY, Herman AG, Pelckmans PA. Neocuproine potentiates the activity of the nitrergic neurotransmitter but inhibits that of S-nitrosothiols. European Journal of Pharmacology 1999;381:151-9.

16. Göçmen C, Göktürk HS, Ertuğ PU, Önder S, Dikmen A, Baysal F. Effect of neocuproine, a selective $\mathrm{Cu}(\mathrm{I})$ chelator, on nitrergic relaxations in the mouse corpus cavernosum. European Journal of Pharmacology 2000;406:293-300.

17. Göçmen C, Kumcu EK, Büyüknacar HS, Önder S, Singirik E. Neocuproine, a Copper (I) Chelator, Potentiates Purinergic Component of Vas Deferens Contractions Elicited by Electrical Field Stimulation. Pharmacology 2005;75:69-75.

18. Kumcu EK, Büyüknacar HSG, Göçmen C, Evrüke IC, Önder S. Differential effect of neocuproine, a copper(I) chelator, on contractile activity in isolated ovariectomized non-pregnant rat, pregnant rat and pregnant human uterus. European Journal of Pharmacology 2009;605:158-63.

19. Göçmen C, Giesselman B, De Groat WC. Effect of neocuproine, a copper(I) chelator, on rat bladder function. Journal of Pharmacology and Experimental Therapeutics 2005;312:1138-43.

20. Benkó R, Lázár Z, Pórszász R, Somogyi GT, Barthó L. Effect of experimental diabetes on cholinergic, purinergic and peptidergic motor responses of the isolated rat bladder to electrical field stimulation or capsaicin. European Journal of Pharmacology 2003;478:73-80.

21. Yu W, Hill WG, Robson SC, Zeidel ML. Role of P2X4 Receptor in Mouse Voiding Function. Scientific Reports 2018;8:1-11.

22. Thériault O, Poulin H, Thomas GR, Friesen AD, Al-Shaqha WA, Chahine M. Pyridoxal-5'phosphate (MC-1), a vitamin B6 derivative, inhibits expressed $\mathrm{P} 2 \mathrm{X}$ receptors. Canadian Journal of Physiology and Pharmacology 2014;92:189-96.

23. Ford AP, Smith SA, Dillon MP. Pharmadynamic (PD) \& pharmacokinetic (PK) properties of AF219: first in class, selective, clinical P2X3 antagonist in development for chronic pain and related conditions. FASEB 2013.

24. Burnstock G. Purinergic signalling: Therapeutic developments. Frontiers in Pharmacology 2017;8:661.

25. Burnstock G. Short- and long-term (trophic) purinergic signalling. Philos Trans $R$ Soc Lond B Biol Sci. 2016;371:20150422.

26. Kitajima S, Ozaki H, Karaki H. The effects of ATP and $\alpha, \beta$-methylene-ATP on cytosolic $\mathrm{Ca} 2+$ level and force in rat isolated aorta. British Journal of Pharmacology 1993;110:263-8. 